\title{
TANGGUNG JAWAB PEMERINTAH DAERAH DALAM PENYELENGGARAAN KEDARURATAN PRA-HOSPITAL MELALUI PUBLIC SAFETY CENTER (PSC) 119 UNTUK PENINGKATAN LAYANAN KESEHATAN DI INDONESIA
}

\author{
Budi Sylvana \\ Alumni Program Studi Magister Ilmu Hukum \\ Pascasarjana Universitas Islam Bandung \\ Email : sherina_aal@yahoo.com
}

\begin{abstract}
Abstrak : Di Indonesia SPGDT (Sistim Pelayanan Gawat Darurat Terpadu) atau yang di negara lain disebut EMS (Emergency Medical Services) belum menunjukkan hasil maksimal, sehingga banyak dikeluhkan oleh masyarakat ketika mereka membutuhkan pelayanan kesehatan. Tujuan penelitian ini Untuk mengetahui implementasi penyelenggaraan kedaruratan pra-hospital melalui Public Safety Center (PSC) 119 dalam peningkatan layanan kesehatan di indonesia. Penelitian ini mempergunakan metode penelitian yuridis normatif, dengan pendekatan yang bersifat kualitatif. Penyusunan tesis ini diawali dengan suatu penelitian yang dimaksudkan untuk mendapatkan masukan yang dipergunakan sebagai bahan pembahasan dan analisis sehingga dapat dipercaya dan dapat dipertanggungjawabkan. Berdasarkan UU No.23 Tahun 2014 pelayanan kesehatan menjadi urusan wajib pemerintah daerah kabupaten/kota, termasuk pelayanan kesehatan gawat darurat. Untuk itu, pelayanan pra-hosptal melalui PSC 119 wajib dibentuk di semua kabupaten/kota untuk menjamin hak masyarakat akan layanan kesehatan.
\end{abstract}

Kata Kunci : Penanggulangan Gawat Darurat Terpadu (SPGDT), Public Safety Center (PSC),Tanggungjawab Pemerintah Daerah

Abstract : Emergency events are usually rapid and sudden making it difficult to predict when they will occur. Not many people realize that some emergency cases are not handled properly. For this reason, it is necessary to strengthen the quality of emergency services through the Integrated Emergency Management System (SPGDT/Sistem Penanggulangan Gawat Darurat Terpadu) which aims at providing first aid in emergency cases in the health sector. SPGDT is guided by a fast response that emphasizes "time saving is life and limb saving", which involves services by the community, health workers, emergency ambulance services, and communication systems. In Indonesia, SPGDT or in other countries it is called EMS (Emergency Medical Services) has not shown maximum results yet, so that many people complain about it when they need health services. The purpose of this study was to determine the implementation of pre-hospital emergencies through the 119 Public Safety Center (PSC) in improving health services in Indonesia. This study used a normative juridical research method using a qualitative approach. The results shows that based on Law Number 23 Year 2014, health services are mandatory for district/city governments, including emergency health services. For this reason, pre-hospital services through 119 PSC must be established in all districts/cities to guarantee the right of the community to health services.

Keywords: Integrated Emergency Management System (SPGDT), Public Safety Center (PSC), Local Government Responsibility

A. PENDAHULUAN

1. Latar Belakang
Hak asasi manusia adalah bentuk pengakuan dan jaminan perlindungan yang 
tertinggi yang diberikan oleh negara terhadap satu jenis hak tertentu, yang mengandung arti bahwa hak tersebut tidak dapat diabaikan atau ditiadakan begitu saja, bahkan oleh negara sekalipun. (Jimly Asshiddiqie, 2007 : 615-618). Sebaliknya, menjadi tugas dan tanggung jawab negara (khususnya pemerintah) untuk dapat melindungi, menegakan, dan memenuhi hak tersebut. (Lihat Pasal 28I ayat (4) UUD1945). Untuk lebih jelasnya, berikut adalah bunyi Pasal $28 \mathrm{H}$ ayat (1) UUD 1945 yang menyatakan bahwa jaminan perlindungan konstitusional terhadap hak kesehatan dan pelayanan kesehatan: "Setiap orang berhak hidup sejahtera lahir dan batin, bertempat tinggal, dan medapatkan lingkungan hidup baik dan sehat serta berhak memperoleh pelayanan kesehatan."

Di era otonomi daerah saat ini sesuai dengan undang-undang No 23 tahun 2014, hak untuk hidup sehat dan memperoleh pelayanan kesehatan, termasuk pelayanan gawat darurat merupakan hak asasi manusia yang wajib diselenggarakan oleh pemerintah daerah. Pada prinsipnya, kebijakan otonomi daerah dilakukan dengan mendesentralisasikan kewenangankewenangan yang selama ini tersentralisasi di tangan pemerintah pusat. Dalam proses desentralisasi itu, kekuasaan pemerintah pusat dialihkan dari tingkat pusat ke pemerintahan daerah sebagaimana mestinya sehingga terwujud pergeseran kekuasaan dari pusat ke daerah kabupaten dan kota di seluruh Indonesia. (Rini Irianti Sundari dkk, 2016, “Kajian Akademis Urusan Pemerintahan Konkuren yang Menjadi Kewenangan Daerah Kabupaten Cianjur Menurut Undang-undang Nomor 23 Tahun 2014 tentang Pemerintah Daerah", Bandung.)

Kejadian gawat darurat biasanya berlangsung cepat dan tiba-tiba sehingga sulit memprediksi kapan terjadinya. Tidak banyak yang menyadari bahwa kasuskasus kegawatdaruratan banyak yang tidak tertangani sebagaimana mestinya. Untuk itu perlu adanya penguatan kualitas pelayanan kegawatdaruratan melalui sistem Penanggulangan Gawat Darurat Terpadu (SPGDT) yang bertujuan memberikan pertolongan pertama pada kasus kegawatdaruratan di bidang kesehatan. SPGDT berpedoman pada respon cepat yang menekankan time saving is life and limb saving, yang melibatkan pelayanan oleh masyarakat, tenaga kesehatan, pelayanan ambulans gawat darurat dan sistem komunikasi.

Di Indonesia SPGDT (Sistim Pelayanan Gawat Darurat Terpadu) atau yang di negara lain disebut EMS (Emergency Medical Services) belum menunjukkan hasil maksimal, sehingga 
banyak dikeluhkan oleh masyarakat ketika mereka membutuhkan pelayanan kesehatan. Meskipun di negara kita hampir di setiap kota terdapat Instalasi Gawat Darurat (IGD) dari semua tipe rumah sakit baik pemerintah maupun swasta, pelayanan ambulans berbagai jenis dan berbagai fasilitas kesehatan lainnya, namun keterpaduan dalam melayani penderita gawat darurat belum sistematis, kurangnya komunikasi baik antar fasilitas kesehatan dan antar tenaga kesehatan sendiri apalagi dengan masyarakat pengguna, sehingga terkesan berjalan sendiri-sendiri.

SPGDT perlu ditingkatkan secara terus menerus untuk memenuhi harapan masyarakat yang selalu menginginkan kualitas pelayanan medis yang bermutu tinggi melalui peningkatan kualitas sumber daya manusia (tenaga medis), peningkatan sarana dan prasarana rumah sakit serta perbaikan mekanisme bantuan kepada korban dari awal tempat kejadian, selama perjalanan menuju fasilitas pelayanan kesehatan, bantuan di fasilitas pelayanan kesehatan sampai pasca cedera. Tercapainya kualitas hidup korban harus tetap menjadi tujuan dari seluruh rangkaian pertolongan yang diberikan.

Berdasarkan Instruksi Presiden RI Nomor 4 tahun 2013 tentang Program Dekade Aksi Keselamatan Jalan untuk pilar ke V Menteri Kesehatan, yang bertanggung jawab meningkatkan penanganan pra kecelakaan meliputi promosi dan peningkatan kesehatan pengemudi pada keadaan/situasi khusus dan penanganan pasca kecelakaan dengan Sistem Penanggulangan Gawat Darurat Terpadu (SPGDT). Menteri Kesehatan, Nila Djuwita F. Moeloek menyatakan bahwa mayoritas daerah tidak peduli dengan penanganan kegawat daruratan bagi masyarakatnya ini terbukti baru sekitar 49 dari total 514 Kabupaten/Kota yang telah membentuk Public Safety Center (PSC) artinya hanya 7,4 \% Kabupaten/Kota di Indonesia yang memiliki fasilitas layanan kegawat daruratan.

(http://www.yankes.kemkes.go.id/readsistem-penanggulangan-gawat-daruratterpadu-spgdt-menggurangi-tingkatkematian-dan-kecacatan-713.html).

Pemerintah telah membuat sistem terkait penanggulangan gawat darurat terpadu, kebijakan ini dilakukan untuk menekan peningkatan jumlah korban/pasien yang meninggal dan mengalami kecacatan pada kejadian gawat darurat yang merupakan dampak dari penanganan gawat darurat yang kurang optimal, juga untuk meningkatkan mutu pelayanan dalam penanganan 
korban/pasien yang dilakukan secara terpadu dan terintegrasi.

Dengan di tandatanganinya peraturan Menteri Kesehatan Nomor 19 Tahun 2016 tentang Sistem Penanggulangan Gawat Darurat Terpadu permasalahan diatas diharapkan dapat terselesaikan secara bertahap. Tugas dan tanggung jawab pemerintah tertulis secara berjenjang didalam Pasal 26 "Pemerintah Pusat, Pemerintah Daerah Provinsi, dan Pemerintah Daerah Kabupaten/Kota memiliki tugas dan tanggung jawab terhadap penyelenggaraan SPGDT “ dan tanggung jawabnya secara jelas dikatakan didalam Pasal 27 ayat (1) "Dalam penyelenggaraan SPGDT sebagaimana dimaksud dalam Pasal 26, Pemerintah Pusat bertugas dan bertanggungjawab:

a. merumuskan dan menetapkan kebijakan SPGDT;

b. memfasilitasi pelaksanaan kegiatan pembentukan PSC di daerah

c. melaksanakan pemantauan dan evaluasi penyelenggaraan SPGDT yang dilaksanakan di daerah;

d. melakukan pembinaan dan pengawasa terhadap penyelenggaraan SPGDT;

e. melakukan koordinasi dengan instansi kesehatan provinsi atau kabupaten/kota terhadap SPGDT; dan

f. menghimpun dan mengkompilasikan data SPGDT tingkat nasional.
Kemudian diperjelas kembali tugas provinsi di dalam ayat (2) " Dalam penyelenggaraan SPGDT sebagaimana dimaksud dalam Pasal 26, Pemerintah Daerah Provinsi bertugas dan bertanggungjawab:

a. mengoordinasikan dan melaksanakan kebijakan/program SPGDT antar kabupaten/kota di wilayahnya;

b. melakukan koordinasi dengan pemangku kepentingan lainnya;

c. memfasilitasi pelaksanaan kegiatan pembentukan dan peningkatan kapasitas serta kemampuan penyelenggaraan SPGDT di wilayahnya;

d. menghimpun data penyelenggaraan SPGDT tingkat provinsi; dan

e. melakukan evaluasi terhadap SPGDT di wilayahnya.

Hermien Hadiati Koeswadji menyatakan pada asasnya hukum kesehatan bertumpu pada hak atas pemeliharaan kesehatan sebagai hak dasar sosial (the right to health care) yang ditopang oleh 2 (dua) hak dasar individual yang terdiri dari hak atas informasi (the right to information) dan hak untuk menentukan nasib sendiri (the right of self determination). (Hermien Hadiati Koeswadji, 1998 : 22). Sejalan dengan hal tersebut Roscam Abing mentautkan hukum kesehatan dengan hak untuk sehat dengan menyatakan bahwa hak atas 
pemeliharaan kesehatan mencakup berbagai aspek yang merefleksikan pemberian perlindungan dan pemberian fasilitas dalam pelaksanaannya. Untuk merealisasikan hak atas pemeliharaan kesehatan bisa juga mengandung pelaksanaan hak untuk hidup, hak atas privasi, dan hak untuk memperoleh informasi. (Roscam Abing, 1998, "Health, Human Rights and Health Law The Move Towards Internationalization With Special Emphasis on Europe" dalam journal International Digest of Health Legislations, Vol 49 No. 1, 1998, Geneve : $103 \& 107)$.

Hukum kesehatan menurut H.J.J. Lennen adalah keseluruhan ketentuanketentuan hukum yang berkaitan langsung dengan pelayanan kesehatan dan penerapan kaidah-kaidah hukum perdata, hukum administrasi negara, dan hukum pidana dalam kaitannya dengan hal tersebut. (Sri Siswati, 2013 : 13). Adapun pengertian lain terkait hukum kesehatan adalah semua ketentuan hukum yang berhubungan langsung dengan pemeliharaan atau pelayanan kesehatan dan penerapannya. (Soekidjo

Notoatmodjo, 2010 : 44).

Permasalahan saat ini yang sering terjadi di daerah adalah pemerintah daerah tidak melihat norma, standar, prosedur dan kriteria yang telah dikeluarkan oleh
Kementerian Kesehatan dalam bentuk peraturan. Kebijakan pembentukan PSC 119 sesuai dengan Inpres No. 4 tahun 2013 dan Permenkes No.19 tahun 2016, pelaksanaannya dinilai sangat lambat. Hal ini terbukti dari data Kementerian Kesehatan bahwa sampai akhir tahun 2018 baru terbentuk 188 PSC Kabupaten/kota, dari total 514 Kabupaten/kota yang ada di Indonesia (sekitar 37\%). Padahal pembentukan PSC 119 merupakan kewajiban pemerintah daerah kabupaten/kota untuk menjamin hak pelayanan kesehatan gawat darurat bagi masyarakat, khususnya layanan pra hospital.

Berdasarkan uraian diatas maka melalui tugas akhir ini penulis mengangkat judul tesisnya mengenai : "Tanggung Jawab Pemerintah Daerah Dalam Penyelenggaraan Kedaruratan Pra-Hospital Melalui Public Safety Center (PSC) 119 Untuk Peningkatan Layanan Kesehatan Di Indonesia".

\section{Identifikasi Masalah}

1. Bagaimana tanggung jawab pemerintah daerah dalam penyelenggaraan kedaruratan pra-hospital melalui pembentukan Public Safety Center (PSC) 119 dihubungkan dengan Undang - Undang No. 23 tahun 2014 tentang Pemerintahan Daerah? 
2. Bagaimana penyelenggaraan kedaruratan pra-hospital melalui Public Safety Center (PSC) 119 dapat meningkatan pelayanan kesehatan masyarakat?

\section{Tujuan Penelitian}

1. Untuk mengetahui dan memahami tanggung jawab pemerintah daerah dalam penyelenggaraan kedaruratan pra-hospital melalui Public Safety Center (PSC) 119.

2. Untuk mengetahui implementasi penyelenggaraan kedaruratan prahospital melalui Public Safety Center (PSC) 119 dalam peningkatan layanan kesehatan di indonesia.

\section{B. PEMBAHASAN}

\section{Pembagian Urusan Pemerintah}

Menurut Undang-undang Nomor 23

\section{Tahun 2014}

Undang-undang No. 23 tahun 2014 ditandatangani pada tanggal 30 September 2014 oleh Presiden RI, menggantikan Undang-undang No. 32 tahun 2004, yang dianggap sudah tidak sesuai lagi dengan perkembangan keadaan, ketatanegaraan, dan tuntutan penyelenggaraan pemerintah daerah. Pasal 9 ayat (1) menyebutkan tuntutan penyelenggaraan pemerintah daerah bahawa urusan pemerintahan terdiri atas urusan pemerintahan absolut, urusan pemerintahan konkuren, dan urusan pemerintahan umum. a. Urusan pemerintahan absolut : merupakan urusan pemerintahan yang sepenuhnya menjadi kewenangan pemerintah pusat yang meliputi politik luar negeri, pertahanan, keamanan, yustisi, moneter dan fiskal nasional, dan agama.

b. Urusan pemerintahan konkuren : merupakan urusan pemerintahan yang dibagi antara pemerintahan pusat, daerah provinsi dan daerah kabupaten/kota, yang terbagi atas urusan pemerintahan wajib dan urusan pemerintahan pilihan.

Melihat pengertian ini, bahwa urusan konkuren adalah urusan yang dilaksanakan secara bersama-sama oleh pemerintah pusat, pemerintah propinsi dan pemerintah kabupaten/kota sesuai dengan kewenangannya. Yang dimaksud urusan pemerintah wajib adalah segala bentuk urusan pemerintahan yang wajib dilaksanakan oleh pemerintahan, baik yang terkait maupun tidak terkait dengan pelayanan dasar. Urusan pemerintah wajib yang berkaitan dengan pelayanan dasar meliputi pendidikan, kesehatan, pekerjaan umum dan penataan ruang, perumahan rakyat dan kawasan pemukiman, ketenteraman, ketertiban umum dan perlindungan masyarakat, serta urusan sosial. Yang tidak terkait dengan pelayanan dasar meliputi urusan tenaga kerja, pemberdayaan perempuan dan perlindungan anak, pangan, pertanahan, 
lingkungan hidup, administrasi kependudukan dan pencatatan sipil, pemberdayaan masyarakat dan desa, pengendalian penduduk dan $\mathrm{KB}$, perhubungan, komunikasi dan informatika, koperasi, usaha kecil dan menengah, penanaman modal, kepemudaan dan olahraga, statistik, persandian, kebudayaan, perpustakaan, kearsipan.

c. Urusan pemerintahan umum : merupakan urusan pemerintahan yang menjadi kewenangan presiden yang meliputi antara lain pembinaan wawasan kebangsaan dan ketahanan nasional, pelestarian Bhinneka Tunggal Ika, serta pemertahanan dan pemeliharaan keutuhan NKRI, pembinaan persatuan dan kesatuan bangsa, pembinaan kerukunan antar suku dan umat beragama, penanganan konflik sosial, koordinasi pelaksanaan tugas, pengembangan kehidupan demokrasi dan pelaksanaan urusan pemerintahan yang bukan kewenangan daerah dan dilaksanakan oleh instansi vertikal.

Dari penjelasan pembagian wewenang di atas, urusan pemerintahan sesuai dengan UU No 23 Tahun 2014 tentang Pemerintah Daerah terbagi menjadi 3 bagian yaitu Urusan Pemerintahan Absolut dimana urusan sepenuhnya berada di tangan pemerintah pusat, tapi pemerintah pusat bisa melimpahkan pelaksanaannya kepada daerah sesuai dengan asas dekonsentrasi. Urusan Pemerintahan Konkuren dimana urusan dibagi antar pemerintah pusat dan daerah propinsi dan daerah kabupaten/kota. Urusan Pemerintahan Umum dimana urusan pemerintahan yang menjadi kewenangan presiden sebagai kepala pemerintahan, yang pelaksanaannya dapat diserahkan kepada gubernur/bupati di daerah masing-masing.

Terkait program PSC 119 masuk dalam urusan konkuren, yang meletakkan urusan pemerintahan dilaksanakan bersama-sama antara pusat, provinsi dan kabupaten/kota menjadikan otonomi yang diamanahkan undang-undang menjadi tidak lagi dilaksanakan secara penuh. Urusan kesehatan, termasuk di dalamnya pelayanan kesehatan gawat darurat, termasuk dalam urusan pemerintahan konkuren dan menjadi tanggung jawab pemerintah daerah sesuai dengan kewenangannya. Sedangkan wewenang pemerintah pusat atas urusan pemerintahan konkuren ini berdasarkan UU No. 23 Tahun 2014 yaitu menetapkan norma, standar, prosedur, dan kriteria dalam rangka penyelenggaraan urusan pemerintahan. Selain itu pemerintah pusat juga bertugas untuk melaksanakan pembinaan dan pengawasan terhadap penyelenggaraan urusan pemerintahan yang menjadi kewenangan daerah. 
Dalam UU No. 23 Tahun 2014 pasal 18 juga disebutkan bahwa pemerintahan daerah memprioritaskan pelaksanaan urusan pemerintahan wajib yang berkaitan dengan pelayanan dasar. Juga ditekankan bahwa pelaksanaan pelayanan dasar pada urusan pemerintahan wajib yang berkaitan dengan pelayanan dasar berpedoman pada standar pelayanan minimal (SPM), yang ditetapkan oleh pemerintah pusat, termasuk bidang kesehatan di dalamnya. Artinya, program pelayanan dasar ini mendapatkan prioritas SDM, anggaran, sarana dan prasarana, serta manajemennya sehingga bisa berjalan dengan baik di tingkat provinsi dan kabupaten/kota.

Program PSC 119 termasuk dalam bidang layanan kesehatan khususnya yang menangani layanan kegawatdaruratan prahospital. Bagi pemerintah daerah sudah seharusnya PSC 119 dibentuk dan mendapat prioritas, baik dari sisi pembiayaan, SDM, sarana dan prasarana, serta manajemennya agar pelayanannya bisa berjalan maksimal.

Pemerintah daerah mempunyai tugas untuk menyusun Perda terkait urusan wajib pelayanan dasar agar dapat dilaksanakan menjadi urusan dan kewenangan otonomi daerah sehingga setiap pemerintah daerah, baik provinsi maupun kabupaten/kota wajib menyusun
Perda urusan pendidikan, Perda urusan kesehatan, Perda urusan pekerjaan umum dan tata ruang, Perda urusan kamtibnas, Perda urusan perumahan rakyat dan Perda urusan sosial. Terkait Perda urusan kesehatan, pelayanan pra-hospital menjadi bagian integral dari layanan kesehatan itu sendiri. Sehingga seyogyanya PSC 119 juga dibuatkan Perda untuk menjamin masyarakat mendapat layanan kesehatan yang optimal.

Menurut pasal 13 UU No. 23 Tahun 2014 pembagian urusan pemerintahan konkuren antara pemerintah pusat, provinsi serta kabupaten/kota didasarkan pada prinsip akuntabilitas, efisiensi, dan eksternalitas serta kepentingan strategis nasional. Berdasarkan prinsip-prinsip tersebut, kriteria urusan pemerintahan yang menjadi kewenangan pemerintah pusat adalah :

1) Urusan pemerintahan yang lokasinya lintas daerah provinsi atau lintas negara.

2) Urusan pemerintahan yang penggunanya lintas daerah provinsi atau lintas negara.

3) Urusan pemerintahan yang manfaat atau dampak negatifnya lintas daerah provinsi atau lintas negara.

4) Urusan pemerintahan yang penggunaan sumber dayanya lebih efisien bila dilakukan pemerintah pusat.

5) Urusan pemerintahan yang peranannya strategis bagi kepentingan nasional. 
Sedangkan kriteria urusan pemerintahan yang menjadi kewenangan provinsi adalah:

1) Urusan pemerintahan yang lokasinya lintas daerah kabupaten/kota.

2) Urusan pemerintahan yang penggunanya lintas daerah kabupaten/kota.

3) Urusan pemerintahan yang manfaat atau dampak negatifnya lintas daerah kabupaten/kota dan/atau

4) Urusan pemerintahan yang penggunaan sumber dayanya lebih efisien bila dilakukan oleh daerah kabupaten/kota.

Sedangkan untuk kriteria urusan pemerintahan yang menjadi kewenangan kabupaten/kota adalah :

1) Urusan pemerintahan yang lokasinya dalam daerah kabupaten/kota.

2) Urusan pemerintahan yang penggunaanya dalam daerah kabupaten/kota.

3) Urusan pemerintahan yang manfaat atau dampak negatifnya hanya dalam daerah kabupaten/kota dan/atau

4) Urusan pemerintahan yang penggunaan sumber dayanya lebih efisien bila dilakukan oleh daerah kabupaten/kota.

Pelaksanaan pembagian urusan tersebut di atas sangat tergantung dari kecepatan pemerintah pusat dalam menerbitkan norma, standar, prosedur dan kriteria (NSPK), yang dijadikan pedoman bagi daerah untuk melaksanakan urusan pemerintahan yang menjadi kewenangan daerah. NSPK terkait PSC 119 sudah dterbitkan pemerintah pusat melalui Peraturan Menteri Kesehatan No. 19 Tahun 2016 tentang Sistem Penanggulangan Gawat Darurat Terpadu (SPGDT). Saat ini implementasinya untuk pembentukan PSC tersebut sangat tergantung dengan regulasi atau Perda yang dibuat pemerintah daerah.

2. Tanggung Jawab Pemerintah Daerah Dalam Penyelenggaraan Kedaruratan Pra-Hospital Melalui Public Safety Center 119

Saat ini Indonesia mengalami transisi epidemiologi dimana penyebab morbiditas dan mortalitas di masyarakat bergeser dari Penyakit Menular ke Penyakit Tidak Menular (PTM). Berdasarkan data Health Sector Review tahun 2014, 3 (tiga) penyakit tertinggi yang menjadi beban penyakit di Indonesia pada tahun 2015 adalah penyakit cerebrovascular, kecelakaan lalu lintas dan penyakit jantung iskemik. Sedangkan Data Sample Registration Survey tahun 2014 menunjukkan tingginya proporsi kematian yang terjadi di rumah sebesar 64,5\% dibandingkan dengan di RS yang sebesar 30,1\%. Menurut WHO, Indonesia menjadi negara ketiga di Asia di bawah Tiongkok dan India dengan total kematian 38.279 akibat kecelakaan lalu lintas tertinggi di tahun 2015, atau 4 orang 
meninggal per jam nya akibat KLL. Tingginya data-data diatas menunjukan bahwa layanan kegawatdaruratan masih belum optimal sehingga masyarakat membutuhkan layanan pertolongan yang cepat, tepat dan berkualitas melalui layanan Public Safety Center 119.

Mendapatkan akses pelayanan kesehatan yang terjangkau dan berkualitas bagi masyarakat merupakan target yang harus dicapai. Salah satu penguatan akses pelayanan kesehatan adalah melalui PSC 119 yang bertujuan memberikan pertolongan pertama pada kasus kegawatdaruratan di bidang kesehatan. PSC 119 berpedoman pada respon cepat yang menekankan time saving is life and limb saving, yang melibatkan pelayanan oleh masyarakat, tenaga kesehatan, pelayanan ambulans gawat darurat dan sistem komunikasi.Selama ini, pelayanan gawat darurat sangat identik dengan IGD, baik Puskesmas maupun Rumah sakit (lebih dikenal dengan pelayanan Intra Hospital). Padahal kenyataannya prosentase kejadian emergensi yang sesungguhnya lebih tinggi terjadi di luar rumah sakit ataupun Puskesmas. Untuk itu seiring dengan meningkatkan kebutuhan gawat darurat bagi masyarakat dan untuk mencegah serta mengurangi angka kecacatan/kematian dibutuhkan unit layanan baru bagi masyarakat (selain
Rumah sakit dan Puskesmas) yaitu Public Safety Center 119, yang memberikan layanan gawat darurat pra hospital, termasuk first responder didalamnya.

Pemerintah telah membuat program terkait penanggulangan gawat darurat terpadu yaitu PSC 119. Kebijakan ini dilakukan untuk menekan peningkatan jumlah korban/pasien yang meninggal dan mengalami kecacatan pada kejadian gawat darurat yang merupakan dampak dari penanganan gawat darurat yang kurang optimal, juga untuk meningkatkan mutu pelayanan dalam penanganan korban/pasien yang dilakukan secara terpadu dan terintegrasi. Dengan ditandatanganinya Peraturan Menteri Kesehatan Nomor 19 Tahun 2016 tentang Sistem Penanggulangan Gawat Darurat Terpadu permasalahan di atas diharapkan dapat terselesaikan secara bertahap. Tugas dan tanggung jawab pemerintah tertulis secara berjenjang di dalam Pasal 26 "Pemerintah Pusat, Pemerintah Daerah Provinsi, dan Pemerintah Daerah Kabupaten/Kota memiliki tugas dan tanggung jawab terhadap penyelenggaraan SPGDT “, dimana PSC 119 itu merupakan bagian integral yang tidak terpisahkan dari SPGDT.

Berdasarkan teori yang sudah dikemukakan di atas dan pentingnya pelayanan pra-hospital bagi masyarakat, 
serta begitu kompleknya layanan yang harus diberikan, maka sesuai dengan kewenangannya (berdasarkan teori kewenangan) seorang kepala daerah memiliki hak untuk mengeluarkan peraturan selama tujuannya adalah untuk peningkatan layanan publik kepada masyarakat. Hal inilah yang lebih dikenal dengan istilah Freies Ermessen, yakni sebuah teori yang memperbolehkan pejabat negara, baik pusat maupun daerah, untuk melakukan sebuah kebijakan yang melanggar dengan undang-undang, dengan tiga syarat (demi kepentingan umum, masih dalam batas wilayah kewenangannya, dan tidak melanggar Azas-azas Umum Pemerintahan yang Baik (AUPB)).

Kompleksitas dalam pelaksanaan berpengaruh kepada beban kerja organisasi perangkat daerah (dinas) yang sudah ada. Peningkatan beban kerja tersebut akan berdampak pada kualitas kinerja pelayanan. Agar kinerja pelayanan PSC 119 tetap optimal, maka diharapkan dinas yang membidangi pelaksanaan PSC 119 membentuk unit pelaksana teknis pada dinas untuk melaksanakan sebagian tugas dan fungsi kegiatan teknis operasional tersebut. Hal inilah yang disebut sebagai pemisahan fungsi regulator dan operator. Regulator adalah pihak yang mengembangkan kebijakan, norma, dan standar bagi pelaksanaan pelayanan publik. Regulatorlah yang akan melakukan fungsi pengawasan dan pengendalian sehingga pelaksanaan pelayanan publik dapat berjalan sesuai koridor yang telah ditetapkan. Sedangkan operator adalah pelaksana pelayanan/ pelaksana tugas teknis operasional yang melakukan perencanaan dan implementasi kegiatan sesuai arahan dari regulator.

Pemerintah Daerah melalui Perangkat Daerah yang memiliki kewenangan dalam pelaksanaan PSC 119, dalam melaksanakan kegiatan teknis operasionalnya dapat membentuk unit pelaksana teknis, hal ini sesuai dengan Peraturan Pemerintah No 18 Tahun 2016 tentang Organisasi Perangkat Daerah, serta Peraturan Menteri Dalam Negeri No 56 Tahun 2010 tentang Perubahan atas Permendagri No 57 Tahun 2007 tentang Petunjuk Teknis Penataan Organisasi Perangkat Daerah.

Ketentuan lain yang mengharuskan pemerintah daerah untuk melaksanakan tugas dan bertanggung jawab terhadap program dari pemerintah pusat adalah Undang-Undang Nomor 23 Tahun 2014 Tentang Pemerintahan Daerah. Setelah berlakunya Undang Undang Nomor 23 Tahun 2014 tentang Pemerintahan Daerah maka daerah diberi otoritas untuk menyelenggarakan semua urusan rumah 
tangga pemerintahan daerahnya, di luar urusan pemerintahan yang menjadi urusan pemerintahan pusat. Hal ini tercermin di dalam ketentuan Pasal 10 ayat (1), yang terdiri atas 6 (enam) urusan pemerintahan absolut yang menjadi urusan pemerintah pusat, yaitu:

1) politik luar negeri;

2) pertahanan;

3) keamanan;

4) yustisi;

5) moneter dan fiskal nasional; dan

6) agama.

Undang-Undang Nomor 23 Tahun 2014 tentang Pemerintahan Daerah, di dalam ketentuan umum pasal 1 angka (2) dan angka (3) menyatakan, "pemerintahan daerah adalah penyelenggaraan urusan pemerintahan oleh pemerintah daerah dan Dewan Perwakilan Rakyat Daerah menurut asas otonomi dan tugas pembantuan dengan prinsip otonomi seluas-luasnya dalam sistem dan prinsip Negara Kesatuan Republik Indonesia sebagaimana dimaksud dalam UndangUndang Dasar Negara Republik Indonesia Tahun 1945", Sedangkan "pemerintah daerah merupakan kepala daerah sebagai unsur penyelenggara Pemerintahan Daerah yang memimpin pelaksanaan urusan pemerintahan yang menjadi kewenangan daerah otonom".
Kementerian Kesehatan bertugas membantu presiden di dalam melaksanakan semua urusan kesehatan sehingga mempunyai kewenangan yang luas terhadap semua upaya kesehatan baik preventif, promotif, kuratif dan rehabilitatif seperti tercantum di dalam Undang-Undang Nomor 36 Tahun 2009 tentang Kesehatan. Dalam melakukan upaya kesehatan guna meningkatkan derajat kesehatan seluruh masyarakat Indonesia kewenangan juga diberikan untuk membuat regulasi terkait kesehatan yang menjadi kewenangannya.

Kecenderungan yang sering terjadi di daerah adalah pemerintah daerah tidak melihat norma, standar, prosedur dan kriteria yang telah dikeluarkan oleh kementerian kesehatan dalam bentuk peraturan. Untuk itu, sesuai dengan UU No. 23/2014 tentang Pemerintah Daerah, mengharuskan pemerintah daerah untuk melaksanakan tugas dan bertanggung jawab terhadap program dari pemerintah pusat. Hal ini hendaknya menjadi perhatian serius dari Pemerintah daerah.

Dalam hal pelayanan kesehatan khususnya pelayanan gawat darurat, hendaknya Pemerintah daerah melaksanakan apa yang sudah diamanahkan oleh Kementerian Kesehatan untuk membentuk Public safety Center 119 di semua kabupaten/kota di Indonesia, 
karena pembentukan PSC 119 merupakan otoritas daerah sesuai dengan Undang Undang Nomor 23 Tahun 2014 tentang Pemerintahan Daerah dimana daerah diberi otoritas untuk menyelenggarakan semua urusan rumah tangga pemerintahan daerahnya, di luar urusan pemerintahan yang menjadi urusan pemerintahan pusat.

\section{Regulasi Daerah Untuk Mengoptimalkan Public Safety Center 119}

I. Pembentukan Peraturan Daerah Secara Umum

Penyelenggaraan Public Safety Center 119 tidak akan berhasil secara keseluruhan apabila tidak ditopang dengan regulasi daerah yang terkait segala bentuk penyelenggaraannya. Rancangan Peraturan Daerah dapat berasal dari Dewan Perwakilan Rakyat Daerah (DPRD) maupun dari Gubernur/Bupati/Walikota. Apabila dalam satu kali masa sidang Gubernur/Bupati dan DPRD menyampaikan rancangan Perda dengan materi yang sama, maka yang dibahas adalah rancangan Perda yang disampaikan oleh DPRD, sedangkan rancangan Perda yang disampaikan oleh Gubernur/Bupati/Walikota dipergunakan sebagai bahan persandingan. Program penyusunan Perda dilakukan dalam satu Program Legislasi Daerah, sehingga diharapkan tidak terjadi tumpang tindih dalam penyiapan satu materi Perda.

Proses pembentukan perda usulan pemerintah daerah maupun perda inisiatif DPRD mekanismenya sama saja, karena kedua lembaga itu apabila membuat peraturan daerah berdasarkan pada peraturan perundang-undangan. Proses pembentukan Perda terdiri dari 3 (tiga) tahap, yaitu:

a. Proses penyiapan rancangan Perda yang merupakan proses penyusunan dan perancangan di lingkungan DPRD atau di lingkungan Pemda, terdiri penyusunan naskah akademik dan naskah rancangan Perda.

b. Proses mendapatkan persetujuan, yang merupakan pembahasan di DPRD.

c. Proses pengesahan oleh Gubernur/Bupati/Walikota dan pengundangan oleh Sekretaris Daerah.

Sebenarnya penentuan arah kebijakan untuk kepentingan daerah bukanlah terletak pada keharusan membuat perda-perda yang banyak, akan tetapi pencocokan sumber daya alam maupun manusia lebih diperhitungkan agar daerah itu dapat menyesuaikan kemampuan pada anggaran pendapatan daerah. Faktor adanya peraturan perundang-undangan yang lebih tinggi dapat juga sebagai bahan refrensi daerah atas kepatuhan terhadap aturan hukum yang menyesuaikan dengan 
kondisi lingkungan didaerahnya. Oleh karena itu agar kebijakan daerah yang efektif, efisiensi, dan accountability dibutuhkan rencana yang matang dengan kadar waktu jangka 1 (satu) tahun, menengah, dan panjang terkonsepkan dalam draf rencana kerja.

Berharap pada pembentukan peraturan daerah membawakan rasa keadilan yang nyata bagi masyarakat daerah agar kelangsungan hidup ekonomi dapat dirasakan. Keadilan adalah perekat tatanan kehidupan bermasyarakat yang beradab. Hukum diciptakan agar agar setiap individu anggota masyarakat dan penyelenggara negara melakukan sesuatu tidakan yang diperlukan untuk menjaga ikatan sosial dan mencapai tujuan kehidupan bersama atau sebaliknya agar tidak melakukan suatu tindakan yang dapat merusak tatanan keadilan.

Keadilan memang merupakan konsepsi yang abstrak. Namun demikian di dalam konsep keadilan terkandung makna perlindungan hak, persamaan derajat dan kedudukan di hadapan hukum, serta asas proporsionalitas antara kepentingan individu dan kepentingan sosial. Sifat abstrak dari keadilan adalah karena keadilan tidak selalu dapat dilahirkan dari rasionalitas, tetapi juga ditentukan oleh atmosfir sosial yang dipengaruhi oleh tata nilai dan norma lain dalam masyarakat.
Kepastian hukum sebagai salah satu tujuan hukum dapat dikatakan sebagai bagian dari upaya mewujudkan keadilan. Bentuk nyata dari kepastian hukum adalah pelaksanaan atau penegakan hukum terhadap suatu tindakan tanpa memandang siapa yang melakukan.

Dengan adanya kepastian hukum setiap orang dapat memperkirakakan apa yang akan dialami jika melakukan tindakan hukum tertentu. Kepastian diperlukan untuk mewujudkan prinsip persamaan dihadapan hukum tanpa diskriminasi. Sedangkan terkait mekanisme penyusunan raperda inisiatif DPRD dimungkinkan dengan tetap memperhatikan, azas-azas pembentukan peraturan perundang-undangan yang baik karena berkaitan dengan APBD, pencabutan Perda, atau perubahan Perda yang hanya terbatas mengubah beberapa materi pengaturan.

4. Penyelenggaraan Kedaruratan PraHospital Melalui Public Safety Center (PSC) 119 Untuk Meningkatan Pelayanan Kesehatan Masyarakat

Saat ini, pelayanan gawat darurat pra hospital dinilai masih belum optimal, dibuktikan dengan tingginya angka kematian akibat penyakit kardiovaskuler, jantung, kecelakaan lalu lintas, maupun yang lainnya. Masyarakat masih kesulitan mencari bantuan jika membutuhkan 
layanan kesehatan gawat darurat, jika gawat darurat tersebut terjadi di luar rumah sakit.

Hal ini menunjukan bahwa layanan kegawatdaruratan di Indonesia masih belum optimal, sehingga masyarakat masih membutuhkan layanan pertolongan yang cepat, tepat dan berkualitas melalui layanan Public Safety Center 119. Lahirnya Public Safety Center 119 juga didasari oleh kesulitan masyarakat memperoleh layanan emergensi, antara lain:

1. Masyarakat tidak mengetahui nomor telepon yang harus dihubungi untuk mendapatkan layanan emergensi.

2. Masyarakat sering sulit mendapatkan layanan ambulans untuk membawa pasien ke rumah sakit ataupun membawa pulang jenasah.

3. Masyarakat sering terkatung - katung karena kesulitan mendapatkan ruang perawatan khususnya perawatan intensif.

4. Masyarakat terbebani dengan biaya layanan prahospital yang sering ditagihkan di awal pelayanan.

Dengan adanya layanan Public Safety Center 119:

1. Mendekatkan akses layanan emergensi pada masyarakat.

2. Layanan emergensi harus lebih aktif menjangkau masyarakat yang membutuhkan, tidak hanya menunggu di RS/fasyankes.

3. Menggunakan nomor tunggal 119, yang terpadu secara nasional, mudah diakses dan bebas pulsa (gratis).

4. Menggunakan pendekatan Public Safety Center (PSC) 119, yang tidak hanya memberikan layanan call center saja namun juga memberikan layanan emergensi langsung ke pasien/korban

5. Pola pembiayaan bersumber dari pemerintah dan/atau CSR.

Layanan emergensi dilakukan terpadu secara nasional, dimana terdapat komunikasi antara Pusat (Kementerian Kesehatan) dengan PSC 119 di daerah serta melibatkan RS, Puskesmas, Klinik, Kepolisian, Pemadam Kebakaran dan BNPB, dll. Antara NCC dan PSC saling terhubung dalam 1 sistem, sistem ini juga mehubungkan antara PSC-PSC yang sudah terintegrasi dengan 119. Bagi Kabupaten/Kota yang sudah memiliki PSC namun belum terintegrasi dengan 119 secara sistem, masyarakatnya tetap dapat menghubungi nomor 119, dimana agen NCC 119 akan menerima telepon tersebut dan akan melakukan komunikasi dengan PSC Kab/Kota melalui nomor telpon lokal yang dimiliki sehingga PSC tersebut dapat segera memberikan layanan kepada masyrakat. Namun kelemahannya, akan membutuhkan waktu yang lebih lama 
dibandingkan dengan PSC yang sudah terintegrasi dengan 119 secara sistem. Bagi Kabupaten/Kota yang saat ini belum memiliki PSC 119, NCC akan membantu memberikan bantuan layanan masyarakat di daerah tersebut.

Dampak positif dari layanan emergensi Public Safety Center 119 :

1. Dengan adanya Public safety Center 119, masyarakat mudah mendapatkan layanan emergensi yang tidak membedakan status ekonomi kaya atau miskin.

2. Terkoordinirnya layanan gawat darurat medis, sehingga memudahkan mendapat informasi cepat untuk mempercepat layanan

3. Memudahkan proses rujukan antar kabupaten/kota maupun provinsi karena tergabung dalam satu sistem.

4. Menurunkan angka kecacatan dan kematian di Indonesia

Arah kebijakan yang tertuang dalam Peraturan Menteri Kesehatan nomor 19 Tahun 2016 Tentang Sistem Penanggulangan Gawat Darurat Terpadu pasal 5 ayat (3) bahwa PSC dibentuk oleh Pemerintah Kabupaten/Kota. Berdasarkan UU No. 23 Tahun 2014 tentang Pemerintah Daerah maka karena PSC 119 merupakan kewenangan pemerintah daerah, Peraturan Menteri Kesehatan No.19 Tahun 2016 ini ditindaklanjuti oleh regulasi di tingkat Pemerintah Daerah. Memperhatikan PP No. 18 Tahun 2016 tentang Organisasi Perangkat Daerah, serta Permendagri No. 56 Tahun 2010 tentang Perubahan Atas Peraturan Menteri Dalam Negeri No. 57 Tahun 2007 Tentang Petunjuk Teknis Penataan Organisasi Perangkat Daerah, bahwa pada satuan kerja perangkat daerah dapat membentuk Unit Pelaksana Teknis (UPT) untuk melaksanakan sebagian kegiatan teknis operasional dinas/badan. Oleh karena itu, Pemerintah Daerah diharapkan dapat membentuk UPT yang melaksanakan kegiatan teknis operasional PSC 119. Diharapkan melalui pembentukan UPTD ini kinerja PSC 119 menjadi lebih baik melalui pemberian pelayanan kepada masyarakat.

\section{PENUTUP}

\section{Kesimpulan}

1. Berdasarkan UU No.23 Tahun 2014 pelayanan kesehatan menjadi urusan wajib pemerintah daerah kabupaten/kota, termasuk pelayanan kesehatan gawat darurat. Untuk itu, pelayanan pra-hosptal melalui PSC 119 wajib dibentuk di semua kabupaten/kota untuk menjamin hak masyarakat akan layanan kesehatan.

2. Berdasarkan teori kewenangan, seorang kepala daerah memiliki hak untuk mengeluarkan peraturan selama 
tujuannya adalah untuk peningkatan layanan publik kepada masyarakat, atau dikenal dengan Fress Ermessen.

\section{Saran}

1. Setiap bupati/walikota hendaknya membentuk unit khusus yang bertanggung jawab terhadap pelayanan Pra-Hospital, yaitu Public Safety Center 119 beserta jejaringnya di wilayah masing-masing, untuk menjamin dan meningkatkan pelayanan kesehatan, khususnya pelayanan gawat darurat prahospital.

2. Kepada setiap Kepala Daerah diharapkan dapat cepat dan tanggap untuk mengeluarkan peraturan yang tujuanya baik untuk peningkatan layanan publik dalam hal kedaruratan Kesehatan.

\section{DAFTAR PUSTAKA}

A. Buku :

Hermien Hadiati Koeswadji, 1998, Hukum

Kedokteran, Studi Tentang

Hubungan Hukum Dalam Mana

Dokter Sebagai Salah Satu Pihak,

PT. Citra Aditya Bakti, Bandung.

Jimly Asshiddiqie, Pokok-Pokok Hukum

Tata Negara Indonesia Pasca

Reformasi, Bhuana Ilmu Populer, Jakarta, 2007.

Jimly Asshiddiqie, Pengantar Ilmu Hukum

Tata Negara, Jilid I (Jakarta,
Penerbit Sekretariat Jenderal dan Kepaniteraan MK RI, 2006).

Soekidjo Notoatmodjo, Etika dan Hukum Kesehatan, (Rineka Cipta,) Jakarta, 2010

Sri Siswati, Etika dan Hukum Kesehatan dalam Perspektif Undang-Undang Kesehatan, Rajawali Pers, Jakarta, 2013.

\section{B. Jurnal :}

Rini Irianti Sundari dkk, 2016, "Kajian Akademis Urusan Pemerintahan Konkuren yang Menjadi Kewenangan Daerah Kabupaten Cianjur Menurut Undang-undang Nomor 23 Tahun 2014 tentang Pemerintah Daerah", Bandung.

Roscam Abing, 1998, "Health, Human Rights and Health Law The Move Towards Internationalization With Special Emphasis on Europe” dalam journal International Digest of Health Legislations, Vol 49 No. 1, 1998, Geneve

\section{Peraturan Perundang-}

Undangan:

Undang-Undang Dasar Negara Republik Indonesia Tahun 1945.

Undang-Undang Nomor 36 tahun 2009 tentang Kesehatan.

Undang-Undang Nomor 23 Tahun 2014 tentang Pemerintahan Daerah.

D. Internet :

http://www.yankes.kemkes.go.id/re ad-sistem- 
Budi Sylvana, Tanggung Jawab Pemerintah Daerah Dalam Penyelenggaraan Kedaruratan Pra-Hospital Melalui...

penanggulangan-

gawat-darurat-

terpadu-spgdt-

menggurangi-tingkat-

kematian-dan-

kecacatan-713.html 